AL-MASHRAFIYAH: Jurnal Ekonomi, Keuangan, dan Perbankan Syariah ISSN (p): 2597-4904 ISSN (e) : 2620-5661

Volume 3, Nomor 1, April (2019), h. 27-42

https://doi.org/10.24252/al-mashrafiyah.v3i1.7424

\title{
PENERAPAN SHARIA COMPLIANCE SEBAGAI PRINSIP SHARIA GOVERNANCE PADA BANK MUAMALAT INDONESIA Tbk. CABANG MAKASSAR
}

\author{
Angriani ${ }^{1}$, Ambo Asse ${ }^{2}$, Lince Bulutoding ${ }^{3}$, Muhammad Wahyuddin Abdullah ${ }^{4}$ \\ Jurusan Akuntansi, Fakultas Ekonomi dan Bisnis, Universitas Hasanuddin ${ }^{1}$ \\ Jurusan Ekonomi Islam, Fakultas Ekonomi dan Bisnis Islam, UIN Alauddin Makassar ${ }^{2}$ \\ Jurusan Akuntansi, Fakultas Ekonomi dan Bisnis Islam, UIN Alauddin Makassar,
}

$$
\text { angrianijamal93@yahoo.com }{ }^{1}
$$

amboasse@yahoo.co.id ${ }^{2}$ lince.bulutoding@uin.alauddin.ac.id ${ }^{3}$, tosir_wahyu@yahoo.com ${ }^{4}$

\begin{tabular}{ll} 
Keywords: & \multicolumn{1}{c}{ ABSTRACT } \\
\cline { 2 - 2 } $\begin{array}{l}\text { Sharia compliance, } \\
\text { Sharia Governance, }\end{array}$ & This research article reviews the application of sharia principles in this case sharia \\
maslabah concept, & compliance to the Bank. Muamalat Indonesia Tbk. Makassar Branch, related to \\
and the concept of & paradigm interpretive and hermeneutic-critical approach that is adhering to the \\
accounting. & critical concept in Islam that according to Al-Madkhali. The result of analysis \\
& showed that the application of the overall principles of sharia will realize a financial \\
& statement with the presentation of earnings that are not only in favor of the bank \\
& alone or is material but also have the value of spiritual, besides charity-oriented \\
& balancing character egoistic and alturistik, character materialistic and spiritualistic \\
& and qualitative and quantitative characters on the financial statements and this \\
& study also shows that the time value of money, historical cost, accrual basic and \\
& substance over form is not in accordance with Islamic principles / values of Islam. \\
& The implication of this study is raising awareness for the regulator to determine the \\
& accounting standards of sharia in particular the basic concepts of accounting in \\
accordance with the values of sharia.
\end{tabular}

\section{Kata Kunci:}

Sharia compliance, Sharia Governance, Konsep Maslahah, Konsep Akuntansi.

\section{ABSTRAK}

Artikel penelitian ini mengulas penerapan prinsip syariah dalam hal ini kepatuhan syariah pada Bank Muamalat Indonesia Tbk Cabang Makassar, terkait penyusunan laporan keuangan. Penelitian ini merupakan penelitian kualitatif, dengan pendekatan paradigma interpretif dan hermeneutik-kritis yang berpegang pada konsep kritis dalam Islam menurut Al-Madkhali. Hasil Analisis tersebut menunjukkan bahwa penerapan prinsip syariah secara keseluruhan akan mewujudkan sebuah laporan keuangan dengan penyajian laba yang tidak hanya menguntungkan bank sendiri atau material tetapi juga memiliki nilai spiritual, disamping karakter penyeimbang amal yang berorientasi egoistik, dan alturistik, karakter materialistik dan spiritualistik dan kualitatif dan kuantitatif pada laporan keuangan dan penelitian ini juga menunjukkan bahwa nilai waktu uang, biaya historis, dasar akrual dan substansi diatas tidak sesuai dengan prinsip/nilai nilai Islam. Implikasi dari penelitian ini adalah meningkatkan kesadaran bagi regulator untuk menentukan standar akuntansi syariah khususnya konsep dasar akuntansi sesuai dengan nilai syariah. 
Angriani, et al. Penerapan Sharia Compliance Sebagai Prinsip...

\section{PENDAHULUAN}

Perkembangan perbankan di negara-negara Islam maupun non-Islam pada dasarnya dipicu oleh perkembangan bisnis yang begitu pesat. Utamanya di Indonesia, berdasarkan data statistik perbankan syariah Bank, dapat diketahui bahwa aset bank syariah pada tahun 2006 sampai dengan 2009 mengalami perkembangan dari tahun ke tahun. Hal itu tentunya memicu munculnya lembaga-lembaga syariah utamanya perbankan syariah. Pada dasarnya operasional bank Islam berbeda dengan bank non-Islam, namun dalam pelaksanaannya bank Islam direkomendasikan untuk mengadopsi standar akuntansi bank non-Islam yang sesuai dengan prinsip-prinsip Islam (Nazer 1997).

Menurut Hameed (2000) masalah utama dalam akuntansi dan operasi bank syariah adalah kurangnya presisi dalam penerapan prinsip-prinsip syariah di perbankan syariah. Secara makro tujuan akuntansi syariah yaitu (1) merupakan dasar dalam perhitungan zakat, (2) memberikan dasar dalam pembagian keuntungan, distribusi kesejahteraan dan pengungkapan terhadap kejadian dan nilai-nilai dan (3) untuk meyakinkan bahwa usaha yang dilakukan perusahaan bersifat islami dan laba yang diperoleh tidak merugikan masyarakat. Hal tersebut ditegaskan Triyuwono (2009) bahwa organisasi bisnis tidak lagi berorientasi profit-oriented atau stockholders-oriented, tetapi berorientasi zakat-oriented dan environment serta stakeholdersoriented.Terlebih hal ini ditegaskan oleh Asrori (2011) bahwa pada dasarnya ada dua tujuan utama akuntansi syariah,pertama sebagai instrumen pertanggungjawaban memenuhi kewajiban kepada Allah (bablun min'allah), individu dan lingkungan masyarakat (bablun min'an-nas) dan keduasebagai instrumen membantu terciptanya keadilan sosial-ekonomi (al-falab).

Simbol agama yang melekat pada bisnis syariah atau perbankan syariah tidak akan selalu menjamin sebuah lembaga menjadi bersih dari perilaku korupsi (misalnya Agustianto dalam Saputra 2010). Hal ini karena konteks muamalah syariah yang berlaku saat ini masih didasarkan pada konsep-konsep konvensionalisme (seperti yang dijelaskan Haryadi 2007). Bukan hanya pada pengelolaan transaksinya tetapi konsep dasar penyusunan laporan keuangan dalam memperlakukan transaksi pun masih menganut konsep-konsep konvensionalisme. Pada teorinya perbankan syariah harus memenuhi prinsip Islam/syariah (Santoso)

. Konsep dasar akuntansi yang dipilih akan menentukan perlakuan terhadap transaksitransaksi tersebut. Sebagaimana dalam Peraturan Bank Indonesia No. 10/ 16/ PBI/ 2008 pada pasal 2 ayat 3 dijelaskan bahwa pemenuhan prinsip Syariah harus dilaksanakan dengan memenuhi ketentuan pokok hukum Islam antara lain prinsip keadilan dan keseimbangan ("adl wa tawazun), kemaslahatan (maslahab) dan universalisme (alamiyah) serta tidak mengandung gharar, maysir, riba, zalim dan objek haram. Salah satunya nilai terpenting dalam prinsip syariah yang juga menjadi tujuan dari prinsip syariah (Maqashid Syariah) yaitu, nilai maslahah. Menurut Dusuki dan Abdullah bahwa prinsip maslahah merupakan cara untuk pengambilan keputusan. Nilai inilah yang harus dikembangkan oleh perbankan syariah ataupun perusahaan berbasis syariah lainnya.

Tulisan ini merupakan sebuah pemikiran konseptual penulis sebagai sebuah pandangan kritis terhadap beberapa konsep akuntansi yang melandasi praktik perbankan syari'ah, khususnya dalam upaya mewujudkan syariah governance. Dalam tulisan ini digunakan pendekatan hermeneutikan yang berelasi dengan berfikir kritis atau yang disebut hermeneutika-kritis (Mulyono 2012). Berfikir kritis sendiri dapat dilakukan dengan konsep kritik. Sebagaiamana dalam Islam, kritik merupakan bentuk upaya tolong menolong dalam kebajikan dan takwa antara sesama muslim dengan jalan saling menasehati sesama muslim. Kitab karya Syaikh Al Madkhali telah menjelaskan metode mengkritik dalam Islam bahwa Al-Qur'an sebagai sumber syari'at Islam memuji sesuatu tanpa menyebutkan kesalahannya dengan tujuan agar jiwa tergerak untuk mengikuti mereka. Begitu juga sebaliknya, Islam mencela sesuatu tanpa menyebutkan kebaikannya dengan tujuan memberikan pelajaran dan peringatan atas kejelekan dan kebrukan tersebut agar tidak ada yang mengikuti perbuatan dan jejak keburukan tersebut. 
AL-MASHRAFIYAH: Jurnal Ekonomi, Keuangan, dan Perbankan Syariah

Volume 3, Nomor 1, April 2019

Al Madkhali pun menyatakan bahwa sikap muwazanab (menyebutkan sisi baik dan sisi buruk) akan menjadikan orang yang dinasehati menjadi lebih bingung, kacau bahkan kadang terjadi apa yang bisa membahayakannya sehingga hilanglah tujuan dari nasihat serta faedahnya (seperti yang dijelaskan oleh Saputro 2010). Konsep inilah yang diajarkan oleh Allah SWT dan Rasul-Nya yang memiliki tujuan mulia untuk mewujudkan kemaslahatan serta mencegah kerusakan yang besar (Saputro 2010).

Munculnya masalah di atas terkait dengan masalah kepatuhan bank syariah pada prinsip-prinsip syariah dalam hal ini syariah compliance. Artikel penelitian ini mengulaas penerapan syariah compliance prinsip ukhuwah, tawazun, universalisme dan maslabah dalam mewujudkan tujuan akuntansi syariah dan menyeimbangkan karakteristik laporan keuangan. Selain itu juga membahas realitas prinsip keadilan ( $a d l)$ dalam mengungkap konsep dasar yang sesuai dan tidak sesuai dengan akuntansi syariah terkait dengan pembayaran tangguhan pada produk murabahah, pengakuan pendapatan pada produk mudharabah, penilaian aset (tanah dan bangunan) untuk zakat dan pihak penanggung biaya perbaikan pada produk ijarah.

\section{LANDASAN TEORI}

\section{Konsep Maslahah}

Maqashid al-syariah adalah tujuan Allah SWT dan Rasul-Nya dalam merumuskan hukum-hukum Islam. Di mana tujuan dari dirumuskannya hukum-hukum Islam yaitu untuk mencapai suatu kemaslahatan manusia. Kata maslahah yang dalam Bahasa dikenal dengan maslahat, berasal dari Bahasa Arab yaitu maslahah. Maslahah ini secara bahasa atau secara etimologi berarti manfaat, faedah, bagus, baik, kebaikan, guna atau kegunaan. Teori maslahah atau istilahnya pertama kali diperkenalkan oleh Imam Malik (W. 97 H.). Sebagaimana menurut Dusuki dan Abdullah maslahah merupakan cara untuk pengambilan keputusan. Al Shatibi dalam Shaharuddin 2010 menyatakan bahwa maslahah:

"'All concerns that promote the subsistence of buman life, the completion of man's livelihood and the acquisition of all his physical and intellectual qualities which are required for him."

Dalam pengertian ini terungkap bahwa semua masalah yang meningkatkan kehidupan manusia, penyelesaian semua masalah kehidupan manusia yang meningkatkan kehidupan manusia, dan perolehan semua kualitas fisik dan intelektualnya yang diperlukan untuknya. "Dan perolehan semua kualitas fisik dan intelektual yang diperlukan untuk. Maslahah. Syari'at pada prinsipnya mengacu kpada kemaslahatan manusia. Tujuan utama syari'at Islam (maqashid al-syari'ah) adalah untuk mewujudkan kemaslahatan umat manusia, baik di dunia maupun di akhirat (Jamaa 2011). Al-Qaradhawi menyatakan: "di mana ada kemaslahatan, di sanalah terdapat hukum Allah. Tujuan mencapai kemaslahatan kahidupan yang bernuansa ekologis" adalah sesuatu yang ingin dituju oleh fikih lingkungan, yaitu kehidupan semua makhluk Tuhan (Thohari, 2013). Konsep maslabah memberikan gambaran bahwa perusahaan tidak hanya semata-mata berorientasi terhadap keuntungan, melainkan harus berusaha untuk memajukan kesejahteraan sosial dan protektif terhadap kebutuhan masyarakat secara keseluruhan.Maslahah merupakan tujuan dari penerapan prinsip-prinsip syariah.

Akuntansi sebuah proses yang menghasilkan laporan keuangan. Tetapi dibalik penyusunannya ada sebuah cerita atau history yang terangkum di dalamnya. Laporan keuangan merupakan hal yang sangat urgent dalam perusahaan. Laporan keuangan menunjukkan bagaimana perusahaan mengelola keuangan mereka.

Laporan keuangan untuk perbankan syariah adalah laporan keuangan yang menunjukkan kepatuhan pada prinsip syariah. Dimana Maqashid Syariah atau tujuan dari penetapan prinsip-prinsip syariah adalah untuk mencapai kemaslahatan. Yang artinya laporan 
Angriani, et al. Penerapan Sharia Compliance Sebagai Prinsip...

keuangan harus mendukung informasi yang dibutuhkan oleh semua pihak yang berkepentingan, baik itu stakeholder maupun shareholder dan laporan keuangan juga harus disusun dan disajikan sesuai dengan penetapan prinsip syariah pada pengelolaannya.

Laporan keuangan (Financial Statement) perusahaan merupakan hasil akhir dari proses akuntansi. Laporan keuangan perusahaan pada dasarnya selalu berusaha untuk memberikan informasi tentang kondisi keuangan dan hasil operasi suatu entitas, badan usaha, atau organisasi (seperti yang dijelaskan Pujiastuti 2009). Tentu penyajian laporan keuangan harus dsesuaikan oleh para penggunanya dan laporan keuangan tidak memihak pada kepentingan salah satu kepentingan saja. Jadi, laporan keuangan adalah output dari proses akuntansi yang berisi informasi untuk para pengguna yang sifatnya tidak memihak (adil) yang dijadikan sebagai alat ukur untuk pengambilan keputusan bagi para penggunanya baik itu stakeholder maupun shareholder.

\section{Syariah Compliance}

Syariah compliance merupakan salah satu bentuk kepatuhan perusahaan khususnya perbankan syari'ah terhadap prinsip-prinsip syari'ah. Shari'ah compliance adalah indikator Islamicity Disclosure Index (IDI) yang relevan sebagai bentuk pertanggungjawaban penyediaan informasi kepatuhan syariah. Pernyataan tersebut didukung oleh para akuntan dan manajer bank syari'ah (seperti yang dinyatakan oleh Asrori). Syariah compliance memperkuat mekanisme kepatuhan syari'ah dan memastikan bahwa semua peraturan perbankan syariah relevan dipenuhi. Syariah compliance merupakan salah satu bentuk pengendalian untuk menuntun apakah lembaga syari'ah telah menjalankan prinsip-prinsip syari'ah. Menurut Islamic Banking Institutions (IBI) (2008) Syariah Compliance didefinisikan sebagai berikut:

"a system of compliance having special emphasis on Syariah aspects with relevant provisions of existing laws, rules, regulations, policies and procedures related to Islamic Banking need to be embedded in the IBI's processes in such a manner that monitoring and reviewing of issues related to Syariah compliance forms part of internal control structure".

Dari sini dijelaskan bahwa kepatuhan syariah adalah sistem kepatuhan yang memiliki penekanan khusus pada aspek Syariah dengan ketentuan yang relevan dari hukum, aturan, peraturan, kebijakan, dan prosedur yang terkait dengan Perbankan Syariah perlu dimasukkan ke dalam proses IBI sedemikian rupa sehingga pemantauan dan peninjauan masalah yang terkait dengan kepatuhan syariah membentuk bagian dari struktur kontrol internal. Syariah Compliance tidak terlepas dengan nilai-nilai Islam. Hal ini berarti pengungkapan yang dilakukan terhadap informasi yang ada pada perusahaan harus berlandaskan dengan prinsip-prinsip Islam. Kepatuhan syariah atau syariah compliance berarti mengikuti standar atau hukum yang telah diatur lembaga syariah yang berwenang menekankan kepatuhan syariah atau kepatuhan pada prinsip-prinsip syariah (seperti yang dijelaskan Cahya 2013, Ghayad 2012 dan Hamza 2013). Sebagaimana firman Allah SWT dalam QS az-Zariyat/51: 56 yang berbunyi:

"Dan Aku tidak menciptakan jin \& manusia kecuali untuk menyembah ('ibadah) Ku".

Sejalan dengan ayat tersebut Syariah compliance sebagai prinsip utama Syariab Governance yang merupakan prinsip pembeda dengan lembaga konvensional (Wardayati 2011). Tujuan dari syariah compliance (kepatuhan terhadap sy ariah) atau Maqashid as-Syariab itu sendiri adalah kemaslahatan. Untuk mencapai kemaslahatan perbankan syariah harus bertanggung jawab kepada semua pihak yang menunjukkan pertanggungjawaban kepada Allah SW'T, melalui penyajian laporan keuangan yang sesuai dengan prinsip syariah. 
AL-MASHRAFIYAH: Jurnal Ekonomi, Keuangan, dan Perbankan Syariah

Volume 3, Nomor 1, April 2019

\section{METODE PENELITIAN}

Pendekatan yang digunakan dalam penelitian ini yaitu pendekatan kualitatif. Pendekatan kualitatif merupakan paradigma penelitian yang menekankan pada pemahaman mengenai masalah-masalah dalam kehidupan sosial berdasarkan kondisi realitas atau natural setting yang holistis, kompleks dan rinci (Bashori 2013). Penelitian ini menggunakan paradigma interpretatif dengan pendekatan hermeneutika-fenomenologi.

Penelitian ini dilakukan dan menggunakan sumber data pada salah satu perbankan syariah, yaitu Bank Muamalat Indonesia Tbk Cabang Makassar. Hal ini didasarkan karena Bank Muamalat Indonesia Tbk merupakan bank umum pertama yang ada di Indonesia yang menerapkan prinsip syariah yang didirikan pada tahun 1991 yang diprakarsai oleh Majelis Ulama Indonesia (MUI) dan Pemerintah Indonesia. Sehingga keberadaannya dianggap sebagai perbankan yang menjalankan operasionalnya berdasarkan prinsip-prinsip Islam.Sehingga perbankan ini dianggap perlu membangun syariah compliance sebagai prinsip utama syariah governance dalam operaionalnya.

Penentuan infoman dilakukan secara purposive dengan memilih 3 orang informan yang dianggap memiliki pengetahuan yang memadai terhadap objek penelitian untuk tujuan tertentu. Informan yang dipilih dengan kriteria mempunyai pengalaman dan pengetahuan tentang pengelolaan produk-produk Bank Muamalat Indonesia Tbk Cabang Makassar, terkait dengan prinsip bagi hasil, sewa-menyewa dan jual-beli. Dimana informan utama yaitu Bapak Ridwan Umar sebagai Sub Branch Manager (SBM) Bank Muamalat Indonesia Cabang Makassar yang bertempat di kantor cabang pembantu Pettarani dan Ibu Nur Qalbi sebagai Sub Branch Manager (SBM) Bank Muamalat Indonesia Cabang Makassar yang bertempat di kantor cabang pembantu Gowa. Sedangkan informan pendukung yaitu Bapak Muhidin sebagai Account Management Financing Bank Muamalat Indonesia Cabang Makassar yang bertempat di kantor cabang pembantu Pettarani.

Teknik analisis data yang digunakan adalah metode interpretatif kualitatif dengan model analisis interaksi. Analisis data dalam penelitian kualitatif dilakukan pada saat pengumpulan data sampai selesainya pengumpulan data.Dalam penelitian ini analisis data dilakukan pada saat wawancara. Adapun tahap dalam analisis data kualitatif dengan menggunakan model analisis interaksi (interactice analysis models), yaitu1)proses coding data, yaitu mengelompokkan didasarkan pada hal-hal yang dapat menunjukkan penerapan prinsip-prinsip syariah yang dibagi menjadi lima prinsip, yaitu ukhuwah, adl, tawazun, maslahah dan universalisme (alamiyah), 2) analisis dengan pendekatan hermeneutika-kritis: interpretasi teks, hal ini dilakukan sesuai dengan metode kritik dalam Islam yang akan dilakukan dengan berdasar kepada prinsipprinsip syariah dengan menghindari sikap muwazanah. Jika dikaitkan dengan penelitian ini dimana penelitian ini berupaya untuk menemukan realitas penerapan prinsip-prinsip syariah dalam hal syariah compliance. Jadi pada tahap analisis kritis ini berusaha menemukan apakah konsep yang diterapkan sudah sesuai dengan prinsip-prinsip syariah, 3) penyajian data (data display) 4) kesimpulan/verifikasi (verification).

\section{HASIL PENELITIAN}

\section{Penerapan Prinsip Syariah Pada Bank Syariah Cabang Makassar Terkait Penyusunan Laporan Keuangan}

\section{Prinsip Ukhuwah dalam Pendapatan dari Aktivitas Pembiayaan}

Prinsip ukhuwah menjelaskan bahwa transaksi syariah menjunjung tinggi nilaikebersamaan dalam memperoleh manfaat sehingga keuntungan tidak diperoleh di atas 
Angriani, et al. Penerapan Sharia Compliance Sebagai Prinsip...

kerugian orang lain. Prinsip ini tentunya dijalankan atas dasar prinsip saling mengenal (ta'aruf), saling memahami (tafahum), saling menolong (ta'awun), saling menjamin (takaful). Prinsip ini ditunjukkan melalui penentuan margin keuntungan, penentuan nisbah bagi hasil dan waktu pembayaran pada pembiayaan yang dilakukan secara kredit yaitu murabahah dan mudharabah.

Dalam penelitian ini diperoleh bahwa Bank Muamalat dalam menentukan margin keuntungan pada produk murabahah, nisbah bagi hasil pada produk mudharabah berdasarkan tawar-menawar antara pihak bank dan nasabah dan menentukan periode pembayaran sesuai dengan kemampuan nasabah. Sebagaimana pernyataan dari Bapak Ridwan Umar mengenai margin keuntungan, pembayaran tangguhan dan nisbah bagi hasi beserta kerugian yang terjadi pada pembiayaan mudharabah;

"Harga yang diperhitungkan bank yaitu harga yang ditawarkan ketika nasabah menyutujui maka terjadilah kesepakatan, dan nisbah bagi hasil itu sendiri berdasarkan penawaran bank, jika nasabah menyanggupi maka terjadi kesepakatan dengan nasabah.Kecuali terjadi kerugian bank lah yang menanggung. Dimana lamanya periode pembayaran sesuai dengan kemampuan nasabah".

Dan pernyataan dari Ibu Nur Qalbi;

"Harga itu ditentukan dari pewaran bank kepada nasabah.Bagi hasil sesuai dengan penawaran bank, jika bank menyetujui barulah terjadi akad". Jangka waktu pembayaran sudah ditentukan pada akad sesuai dengan kesepakatan dengan nasabah".

Dari jawaban kedua informan tersebut menunjukkan bahwa prinsip ukhuwah telah diterapkan pada Bank Muamalat Cabang Makassar karena pengambilan keputusan berdasarkan kesepakatan bersama antara pihak bank dan nasabah, dan hasil penelitian tersebut sejalan dengan firman Allah SWT dalam QS.al-Maidah/5:1 yang berbunyi;

Adanya kesepakatan dalam melakukan pembayaran kepada bank mengindikasikan bahwa bank menjunjung tinggi nilai kebersamaan karena pembayaran tangguhan menunjukkan bank mau dan mampu membantu nasabah dalam memenuhi kebutuhan baik itu dari pembelian barang kepada bank maupun bantuan dana dalam permodalan usaha yang dijalankan oleh nasabah yang pembayarannya dilakukan sesuai dengan kemampuan nasabah. Artinya keputusan yang ditetapkan dalam akad tidak berlaku secara sepihak melainkan bank menetapkan keputusan berdasarkan pertimbangan kemampuan nasabah atau dalam hal ini ada kesepakatan antara bank dan nasabah.

Kesepakatan di dalam akad harus dijalankan karena kesepakatan tersebut merupakan persetujuan antara bank dan nasabah yang didasarkan pada nilai-nilai persaudaraan.Sehingga akad yang telah dibuat antara bank dan nasabah harus dijalankan. Adanya kesepakatan dalam melakukan pembayaran kepada bank mengindikasikan bahwa bank menjunjung tinggi nilai kebersamaan karena pembayaran tangguhan menunjukkan bank mau dan mampu membantu nasabah dalam memenuhi kebutuhan baik itu dari pembelian barang kepada bank maupun bantuan dana dalam permodalan usaha yang dijalankan oleh nasabah yang pembayarannya dilakukan sesuai dengan kemampuan nasabah. Sehingga keuntungan yang ditetapkan adalah ketentuan yang berdasarkan pada kesepakatan antara pihak bank dan nasabah. Artinya bank memperoleh keuntungan atas dasar kebersamaan dalam memperoleh manfaat berupa keuntungan dari penjualan produk murabahah tersebut.

Begitu juga dalam penentuan nisbah bagi hasil antara bank dan nasabah. Bank Muamalat dalam menentukan nisbah bagi hasil sesuai dengan tawaran bank kepada nasabah yang jika disetujui maka nasabah dan bank melakukan akad mudharabah. Hal itu berarti adanya kesepakatan yang dibuat antara pihak bank dan nasabah. Margin keuntungan dan nisbah bagi hasil yang ditetapkan tentunya berdampak pada penyajian pendapatan pada laporan keuangan Bank Muamalat. Ketika margin keuntungan dan nisbah bagi hasil telah 
AL-MASHRAFIYAH: Jurnal Ekonomi, Keuangan, dan Perbankan Syariah

Volume 3, Nomor 1, April 2019

ditetapkan berdasarkan prinsip ukhuwah berarti penyajian laporan keuangan Bank Muamalat Cabang Makassar telah menjunjung tinggi nilai-nilai persaudaraan sebagaimana firman Allah SWT dalam QS al-Hujurat/49:10, "orang-orang mukmin itu bersaudara" dalam hal ini nasabah dan pihak bank terikat dalam ikatan persaudaraan yang mewajibkan pihak bank dan nasabah menjaga silaturahmi dalam menjalin hubungan kerjasama ekonomi. Sehingga dengan adanya prinsip ukhuwah mencerminkan besarnya pendapatan yang disajikan dalam laporan keuangan berdasarkan kesepakatan dan diperoleh dari manfaat yang diperoleh nasabah bukan dari kerugian mitra ataupun nasabah.

\section{Prinsip Tawazun, Universalisme dan Maslahah Untuk Akuntansi Syariah}

Prinsip tawazun, universalisme dan maslabah merupakan prinsip yang harus dijalankan oleh perbankan syariah yaitu Bank Muamalat Cabang Makassar. Adanya prinsip ini mengarahkan pengelolaan bank syariah yang sesuai dengan nilai-nilai Islam. Prinsip-prinsip ini juga membentuk akuntansi yang bernilai Islam atau yang dikenal dengan akuntansi syariah. Prinsip tawazun mengarahkan Bank Muamalat untuk tidak berfokus pada maksimalisasi keuntungan untuk kepentingan pemilik modal saja atau shareholder, tetapi manfaat juga harus difokuskan pada pihak yang dapat merasakan manfaat adanya suatu kegiatan ekonomi (masyarakat umum dan lingkungan masyarakat.

Prinsip universalisme mengarahkan Bank Muamalat menjalankan operasi untuk semua pihak yang berkepentingan (stakeholder) tanpa membeda-bedakan. Sebagaimana firman Allah SWT dalam QS Al-Anbiya'/21:107 yang menjelaskan bahwa Allah SWT tidak menciptakan manusia melainkan untuk (menjadi) rahmat bagi seluruh alam. Dari penjelasan tersebut diperoleh bahwa Bank Muamalat menjalankan operasionalnya harus dilandaskan dengan sifat netral, artinya tidak membeda-bedakan antara pihak-pihak yang berkepentingan dalam pengelolaan Bank Muamalat dalam hal ini yang berdampak pada informasi yang disajikan dalam laporan keuangan.

Sedangkan prinsip maslahah mengarahkan Bank Muamalat untuk memberikan manfaat atau kebaikan untuk semua pihak (stakeholder termasuk lingkungan masyarakat) sebagai bentuk pertanggungjawaban kepada Allah SWT. Sebagaimana firman Allah SWT dalam QS Al-Baqarah/2:195 "janganlah kamu jatuhkan (diri sendiri) ke dalam kebinasaan dengan tangan sendiri, dan berbuat baiklah". Dimana hal ini menegaskan bahwa Bank Muamalat sebagai bank yang berdasarkan pada prinsip maslahah harus melakukan kebaikan-kebaikan baik itu yang berhubungan dengan proses pengelolaannya maupun hasil pengelolaannya yang tentunya akan memberikan manfaat kepada semua stakeholdernya. Dari ketiga prinsip tersebut sangat jelas bahwa Bank Muamalat sebagai bank yang berbasis syariah harus menyeimbangkan tujuan hidup dunia dan tujuan hidup akhirat.

Bank Muamalat sebagai bank yang berbasis syariah mewujudkan ketiga prinsip tersebut melalui zakat yang dibuktikan adanya laporan zakat untuk keseluruhan bank. Untuk mewujudkan laporan zakat tersebut maka Bank Muamalat membentuk suatu badan untuk mengelola penggunaan dana zakat yaitu Baitulmaal Muamalat. Dalam hal ini dana-dana tersebut disalurkan oleh Baitulmaal Muamalat, sedangkan Bank Muamalat sendiri merupakan sumber dari dana-dana tersebut. Laporan zakat yang disusun pun mewakili seluruh Bank Muamalat yang ada. Karena Baitulmaal Muamalat hanya ada satu. Penggunaan dana CSR dan zakat memang diperuntukan untuk masyarakat umum dan lingkungan sekitar, seperti dalam kegiatan produktif Bank Muamalat membantu permodalan para petani maupun pengusaha kecil dan kegiatan non-produktif seperti bantuan untuk bencana alam, pembangunan rumah sakit dan bantuan yang ditujukan kepada anak yatim dan dhuafa. Sebagaimana dinyatakan oleh Ibu Nur Qalbi dalam penelitian ini;

"Bank tentunya melakukan kegiatan sosial yang berasal dari dana zakat. Karena zakat merupakan kewajiban". 
Angriani, et al. Penerapan Sharia Compliance Sebagai Prinsip...

Dan pernyataan ini didukung oleh Bapak Muhidin, dengan mengatakan,

"Zakat yang dikeluarkan oleh bank sendiri dikelola oleh Baitulmaal Muamalat. Zakat digunakan untuk tujuan kegiatan sosial bank. Zakat tersebut ditujukan kepada masyarakat umum".

Kedua jawaban dari informan ini tentunya memberikan kejelasan betapa pentingnya kehadiran zakat di tengah-tengah kegiatan operasional yang dijalankan oleh Bank Muamalat Cabang Makassar. Karena zakat dapat mengindikasikan bahwa Bank Muamalat Cabang Makassar menerapkan prinsip tawazun, universalisme dan maslabah. Dan zakat menjadi kewajiban tersendiri yang harus dijalankan oleh Bank Muamalat Cabang Makassar sebagai bank yang berlandaskan pada nilai-nilai Islam. Sebagaimana zakat yang dianggap sebagai kewajiban oleh bank sejalan dengan firman Allah SW'T dalam QS at-Taubah/9:60, yang berbunyi:

"Sesunggubnya zakat itu hanyalab untuk orang-orang kafir, orang miskin, amil zakat, yang dilunakekan batinya (mualaf), untuk (memerdekakan hamba sabaya, untuk (membebaskan) orang yang berbutang, untuk jalan Allah, dan untuk orang yang sedang dalam perjalanan, sebagai kewajiban dari Allah. Allab Maha Mengetabui, Mababijaksana".

Ayat tersebut menjelaskan bahwa zakat merupakan kewajiban dari Allah SWT yang harus dijalankan oleh Bank Muamalat Cabang Makassar. Adanya zakat sebagai kewajiban, hal tersebut berarti zakat merupakan suatu amanah dari Allah SWT yang harus dilaksanakan dan dipertanggungjawabkan. Dan inilah yang direalisasikan oleh Bank Muamalat Cabang Makassar dengan melakukan pengelolaan dana zakat melalui Baitulmaal Muamalat. Kemudian dipertanggungjawabkan melalui laporan zakat Bank Muamalat Cabang Makassar. Zakat yang dibayarkan oleh bank tidak hanya berpegang pada kepentingan pemegang saham saja, tetapi zakat juga berfokus pada kepentingan masyarakat umum termasuk lingkungan masyarakat. Hal itu berarti laporan zakat pada Bank Muamalat Cabang Makassar sebagai pertanggungjawaban kepada shareholder selaku pemilik modal/pemegang saham dan sebagai pertanggungjawaban kepada Allah SWT sebagai pemilik utama dan hakiki sumber daya yang digunakan oleh bank melalui pertanggungjawaban kpada masyarakat umum dan lingkungan masyarakat (stakeholder).

Prinsip tawazun, universalisme dan maslahah membentuk akuntansi yang bernilai Islam/syariah melalui pengelolaan zakat. Hal itu karena zakat yang dikelola oleh Bank Muamalat merupakan wujud penerapan ketiga prinsip tersebut. Implikasi dari penerapan prinsip-prinsip tersebut bahwa tujuan dari Bank Muamalat bukan lagi profit-oriented tetapi zakatoriented. Karena Bank Muamalat berpegang pada zakat-oriented maka ukuran kinerja tidak lagi dilihat dari pencapaian laba bersihnya (net profit) tetapi kriteria ukuran kinerja dilihat dari pembayaran zakat yang optimum oleh Bank Muamalat Cabang Makassar.

Hal yang sama dari pengertian metafora zakat menurut Triyuwono (2009) bahwa secara ideal akuntansi syariah harus dibangun berdasarkan pada "konsep nilai zakat". Dengan adanya penerapan zakat berarti Bank Muamalat telah menjaga keseimbangan anatara sifat materialistik dengan sifat spriritualistik. Karena fokus bukan hanya pencapaian keuntungan yang bermafaat bagi kehidupan dunia tetapi juga kegiatan sosial yang bermanfaat bagi kehidupan di akhirat. Zakat juga menunjukkan bahwa Bank Muamalat tidak hanya berfokus pada satu kepentingan yaitu pemilik saham tetapi Bank Muamalat juga mementingkan kepentingan masyarakat umum dan lingkungan masyarakat sebagai pertanggungjawaban kepada Allah SWT. Selain itu zakat juga memiliki nilai bahwa Bank Muamalat menciptakan manfaat bagi pihak-pihak yang memang seharusnya menerima manfaat dari aktivitas ekonomi Bank Muamalat yaitu semua stakeholder (pemegang saham, masyarakat dan lingkungan masyarakat). Karena zakat menunjukkan pertanggungjawaban kepada Allah SWT.

Zakat-oriented memberikan nilai kepada Bank Muamalat bahwa pencapaian laba bukan merupakan tujuan akhir tetapi yang menjadi tujuan akhir adalah zakat. Untuk itu Bank Muamalat harus hadir dengan menunjukkan pembayaran zakat yang optimal untuk 
memberikan kejelasan bahwa Bank Muamalat telah melakukan kinerja yang baik utamanya dengan menunjukkan laporan zakat. Makna zakat bukan hanya sekedar sumbangan tetapi juga memiliki nilai pembersihan serta merupakan hal yang wajib bagi muslim. Bahkan dengan adanya zakat-oriented, memberikan makna bahwa unsur terpenting dalam akuntansi syariah bukanlah kinerja operasional (laba bersih), tetapi kinerja dari pandangan semua stakeholder dan nilai sosial yang didistribusikan secara adil kepada para stakeholder.

Dengan adanya prinsip tawazun, universalisme dan maslahah maka memberikan implikasi bagi perangkat khusunya Bank Muamalat Cabang Makassar untuk merefleksikan zakat sebagai tujuan dan menjadi ukuran kinerja bagi seluruh stakehodernya dan bagi nilai sosial Bank Muamalat Cabang Makassar. Zakat memberikan keseimbangan terhadap laporan keuangan akuntansi syariah, seperti yang dijelaskan bahwa tujuan dasar dari laporan keuangan akuntansi syariah yaitu menjadi bingkai yang akan menentukan bentuk dan elemen dari laporan keuangannya. Keseimbangan yang dimaksud adalah perpaduan antara karakter egoistik dan altruistik yang sejalan dengan prinsip universalisme, perpaduan antara karakter materialistik dan spiritaualistik yang sejalan dengan prinsip tawazun dan perpaduan antara karakter kuantitatif dan kualitatif sejalan dengan prinsip maslahah.

Perpaduan antara karakter egoistik dan alturistik memberikan indikasi bahwa laporan keuangan Bank Muamalat Cabang Makassar tidak hanya berfokus pada pencapaian laba untuk sharebolder (pemegang saham) tetapi Bank Muamalat Cabang Makassar juga harus berfokus pada kepentingan stakeholder lainnya yaitu melalui penyajian laporan zakat. Perpaduan antara karakter materialistik dan spiritalistik memberikan indikasi bahwa laporan keuangan Bank Muamalat Cabang Makassar tidak hanya menunjukkan kinerja untuk pencapaian laba tetapi Bank Muamalat Cabang Makassar juga harus menunjukkan kinerja yang bernilai sosial sebagai pertanggungjaawaban kepada Allah SWT. Dan perpaduan antara karakter kuantitatif dan kualitatif memberikan indikasi bahwa laporan keuangan harus menyajikan informasi yang tidak hanya menyajikan informasi kuantitatif saja atau yang sifatnya keuangan/materi saja, tetapi laporan keuangan juga harus menyajikan informasi kualitatif yang berhubungan dengan realitas spiritual yang sifatnya tidak bisa diukur. Dengan adanya kedua karakter tersebut maka menciptakan kebermanfaatan nilai informasi yang disajikan oleh Bank Muamalat Cabang Makassar karena informasi tersebut memenuhi pertanggungjawaban kepada Allah SWT yang ditunjukkan dengan pemenuhan kepentingan semua stakeholder (pemegang saham (shareholder), masyarakat dan lingkungan masyarakat).

\section{Prinsip Adl (Keadilan) Terkait Konsep Dasar Akuntansi}

Keadilan ('adalah) berarti menempatkan sesuatu pada tempatnya atau posisinya. Prinsip keadilan pada aturan muamalah yaitu melarang adanya unsur riba, kezaliman, maysir dan gharar. Bank Syariah sebagai bank yang berbasis syariah harus menjalankan prinsip keadilan dengan menjauhi unsur-unsur tersebut. Prinsip keadilan dalam penyajian laporan keuangan mendukung kebutuhan informasi semua stakeholder, artinya tidak ada kebohongan dan hal yang disembunyikan.

Hal itu berarti laporan keuangan harus menyajikan informasi yang benar-benar terjadi bukan suatu kebohongan atau rekayasa. Dengan mewujudkan hal tersebut maka laporan keuangan akan menciptakan nilai keadilan karena laporan keuangan yang disajikan memberikan informasi yang sebenarnya. Dan hal tersebut mewujudkan keseimbangan informasi untuk seluruh stakeholdernya yang berarti laporan keungan tidak menyesatkan dan menjadi informasi terpenting dalam pengambilan keputusan. Laporan keuangan yang menegakkan nilai keadilan akan mencerminkan bahwa laporan keuangan tidak hanya berfokus pada tujuan dunia saja (pencapaian laba) tetapi tujuan akhirat juga diutamakan. Dan dengan terhindarinya laporan keuangan berarti Bank Syariah Cabang Makassar telah berusaha beriman kepada ayat-ayat Allah SWT. Dan hal ini diwujudkan dengan menghindari unsur-unsur sebagai berikut: 
Angriani, et al. Penerapan Sharia Compliance Sebagai Prinsip...

\section{Unsur Riba dalam Pembayaran Tangguhan Pembiayaan Murabahah}

Riba atau bunga diartikan sebagai tambahan pada pokok piutang yang dipersyaratkan dalam transaksi pinjam meminjam. Riba yang dimaksud dalam tulisan ini yaitu tambahan pembayaran atas transaksi murabahah yang tidak secara tunai, selain keuntungan akibat adanya penangguhan waktu. Hal ini dilakukan dengan melihat jumlah pembayaran transaksi murabahah secara tunai dan secara tangguhan dalam akad yang sama.

Hal ini karena pembayaran murabahah pada bank syariah diberlakukan secara konsisten antara pembayaran tunai dengan pembayaran tangguhan. Sebagaimana contoh yang diberikan oleh Bapak Ridwan Umar mengenai perhitungan jumlah pembayaran tangguhan;

"Misalnya murabahah, nasabah memesan barang pada bank dengan harga Rp 1.000.000.000,-, dengan margin keuntungan Rp 300.000.000,-. Maka secara tunai maupun angsuran jumlah pembayarannya tetap sama Rp 1.300.000.000,- Maka Rp 1.300.000.000,- adalah jumlah yang harus dibayar sampai selesainya waktu pembayaran".

Pernyataan tersebut juga didukung oleh Ibu Nur Qalbi;

"Jumlah pembayaran sesuai dengan jumlah pada awal akad, yaitu harga pembelian barang ditambah keuntungan yang diharapkan".

Hal itu berarti Bank Muamalat Cabang Makassar dalam menetapkan jumlah pembayaran pada pembiayaan dilakukan secara konsisten.Dan margin keuntungan hanya ditetapkan satu kali diawal akad.

Pada hakekatnya pembayaran tangguhan yang bebas dari unsur riba hanya berdasarkan pokok pinjaman dan margin keuntungan yang telah ditentukan sebelumnya pada produk pembiayaan murabahah dan mudharabah Bank Syariah. Tidak ada unsur penambahan pembayaran akibat penambahan waktu pembayaran, karena pada dasarnya semua tambahan kecuali pokok pembayaran dan keuntungan yang telah disepakati merupakan bentuk riba terlebih penerapan nilai waktu dari uang. Hal tersebut sejalan dengan firman Allah SWT dalam QS ar-Rum/30: 39.

'Dan sesuatu riba (tambahan) yang kamu berikan agar harta manusia bertambah maka tidak bertambah dalam pandangan Allah. Dan apa yang kamu berikan berupa rakat yang kamu maksudkan untuk memperoleh keridaan Allah maka itulah orang-orang yang melipatandakan (pabalanya)".

Salah satu bentuk dari praktek riba adalah adanya pertambahan nilai dari uang yang harus dibayarkan ketika terjadi pembayaran tangguhan. Hal tersebut didasarkan nilai uang di masa sekarang tidak sama dengan nilai uang di masa yang akan datang, artinya konsep ini mengacu pada time value of money. Nilai waktu dari uang mengacu pada konsep dasar penyusunan laporan keuangan yaitu historical cost. Historical cost memaknai bahwa nilai uang sekarang lebih tinggi dibandingkan nilai uang di masa yang akan datang. Konsep laba dalam pendekatan historical cost secara implisit mengakui adanya time value of money (lihat misalnya Wibowo 2007). Adanya nilai waktu dari uang (time value of money) karena uang sendiri dijadikan sebagai satuan ukur. Adanya nilai waktu dari uang akibat riba memang akan memperlihatkan bahwa pendapatan yang diperoleh bank namun pendapat yang demikian tersebut tidak akan membawa kebaikan karena hanya menguntungkan dari pihak bank saja.

Riba (tambahan) yang diberlakukan untuk menambah harta manusia tidaklah menambah balasan di sisi Allah SWT. Begitu juga dari segi pembayaran tangguhan, tambahan atas pembayaran selain pembayaran pokok dan margin keuntungan yang telah ditentukan tidak akan menambah pahala di sisi Allah SWT karena adanya penambahan keuntungan dari ketidakikhlasan atas pinjaman tersebut. Hal ini mendasari bahwa konsep dasar historical cost yang mengandung prinsip time value of money tidaklah sesuai dengan nilai-nilai syariah karena masih mengandung unsur riba. Hal itu karena time value of money memberikan indikasi bahwa 
AL-MASHRAFIYAH: Jurnal Ekonomi, Keuangan, dan Perbankan Syariah

Volume 3, Nomor 1, April 2019

pembayaran yang dilakukan secara tangguh akan menambah jumlah pembayaran karena nilai uang dari waktu ke waktu mengalami penurunan.

\section{Unsur Gharar dalam Pengakuan Pendapatan Pembiayaan Mudharabah}

Gharar diartikan sebagai ketidakjelasan atau eksploitasi informasi. Gharar dalam penelitin ini yaitu adanya ketidakpastian informasi dalam laporan keuangan berupa pendapatan yang sesungguhnya diterima oleh bank. Hal ini dilakukan dengan mengidentifikasi waktu terjadinya bagi hasil antara bank sebagai pemilik dana dan nasabah sebagai pengelola dana.

Hal yang sangat krusial dalam produk pembiayaan bagi hasil adalah pengakuan pendapatan.Produk pembiayaan yang menjadi fokus pada bagian ini yaitu mudharabah. Bank Muamalat Cabang Makassar melakukan bagi hasil dan mengakui pendapatan ketika keuntungan usaha yang dijalankan telah diterima dalam bentuk kas oleh nasabah. Sebagaimana pernyataan dari Bapak Ridwan Umar;

"Bagi hasil dilakukan ketika akhir bulan setiap periode pembayaran setelah keuntungan dapat direalisasi.

Pernyataan lain dari Bapak Ridwan Umar mengenai jumlah pembayaran tidak dapat ditentukan dengan pasti karena pendapatan tidak dapat diketahui secara langsung, yaitu;

"Dan jumlah pembayaran pun tidak tetap karena keuntungan dari koperasi belum dapat diketahui secara langsung".

Pernyataan tersebut juga didukung oleh pernyataan Ibu Nur Qalbi;

"Setelah pendapatan atau keuntungan terealisasi".

Dalam hal ini berarti bank menerapkan konsep cash basic. Dan hal tersebut menegaskan, walaupun transaksi telah terjadi namun pendapatan atau keuntungan dari usaha yang dijalankan tidak dapat langsung diakui. Artinya pendapatan hanya dapat diakui pada saat angsuran diterima secara tunai. Dan hal tersebut bertolak belakang dengan konsep accrual basic.

Dari pernyataan tersebut sangatlah jelas bahwa accrual basic sebagai konsep dasar dalam pengakuan pendapatan tidak tepat untuk diterapkan pada produk bagi hasil mudharabah. Accrual basic merupakan metode pengakuan pendapatan ketika transaksi telah terjadi walaupun pendapatan belum diperoleh dalam bentuk kas (Muchlis 2011). Penggunaan accrual basic pada pengakuan pendapatan produk bagi hasil akan menghasilkan ketidakjelasan. Artinya pendapatan yang akan dilaporkan bukan merupakan jumlah pasti yang diterima oleh pemilik dana dan pengelola dana karena pengakuan pendapatan bukan atas dasar kas yang benar-benar ada atau diterima oleh pengelola dana. Sehingga adanya ketidakpastian tersebut memunculkan risiko bagi pemilik modal. Sehingga pengembalian dari modal memiliki risiko. Sedangkan bagi hasil yang dilakukan antara pihak pemilik dana dan pengelola dana harus dari jumlah kas yang benar-benar dapat didistribusikan langsung. Dan hal tersebut tidak dapat dilakukan dengan menerapkan konsep accrual basic. Sebagaimana dalam Al-Qur'an Q.S. Luqman/31:34, memberikan indikasi bahwa accrual basic (khususnya pendapatan) tidak diperkenankan

\section{"Dan tidaklah seorangpun tabu apa yang akan diusabakannya besok".}

Dari hal inilah sangat jelas bahwa pengakuan pendapatan dengan accrual basic atau mengakui pendapatan sebelum adanya kas diterima tidak diperbolehkan karena mengandung ketidakjelasan apakah kas tersebut bisa diterima dikemudian hari atau akan menjadi risiko tidak tertagihnya hak dari bank itu sendiri. Accrual basic mengandung ketidakjelasan, hal itu karena 
Angriani, et al. Penerapan Sharia Compliance Sebagai Prinsip...

masih ada piutang yang belum tertagih yang berasal dari pendapatan. Sementara ketika pendapatan tersebut diakui sebelum menjadi kas atau dalam hal ini piutang, berarti masih ada kemungkinan bahwa pendapatan tersebut belum jelas apakah dapat diterima dikemudian hari atau akan menjadi pendapat yang tidak bisa direalisasikan karena munculnya piutang tak tertagih. Hal itu berarti accrual basic tidak bisa memberikan gambaran pasti mengenai pendapatan yang real dimiliki oleh bank.

\section{Unsur Maysir dalam Penilaian Aset Tetap Untuk Pembayaran Zakat}

Maysir diartikan sebagai sikap spekulatif dan tidak berhubungan dengan produktivitas. Maysir dalam tulisan ini yaitu adanya sikap spekulatif dalam penilaian aset dengan tujuan untuk menekan pembayaran zakat. Hal ini dilakukan dengan mengidentifikasi metode penilaian aset nonkas yang dieperoleh untuk diperdagangkan (tanah dan bangunan). Bank Syariah sebagai bank yang berbasis syariah menerapkan zakat, yang tentunya jumlah dari pembayaran zakat setiap tahunnya berbeda karena didasarkan atas aset yang dimiliki. Tinggi atau rendahnya jumlah zakat yang dikeluarkan oleh bank sangat tergantung dasar penilaian atas aset yang menjadi objek zakat.

Dari penelitian yaang dilakukan pada Bank Muamalat, diperoleh bahwa untuk menilai aset tetap maka bank berpegang pada nilai pasar yang dapat direalisasikan.Hal itu juga sejalan dengan penilaian jaminan oleh bank yang menggunakan nilai pasar.Diidentifkasikan bahwa Bank Muamalat melakukan penilaian aset nonkas (tanah dan bangunan) dengan menggunakan metode net realizable value. Sebagaiman pernyataan dari Ibu Nur Qalbi;

"Untuk penilaian terhadap aset tidak bergerak bank dilakukan berdasarkan harga sekarang artinya nilai yang dapat direalisasikan".

Untuk menilai aset tetap maka bank berpegang pada nilai pasar yang dapat direalisasikan. Hal itu juga sejalan dengan penilaian jaminan oleh bank yang menggunakan nilai pasar. Net realizable value diartikan sebagai nilai bersih yang dapat direalisasikan atas aset dengan berpatokan pada nilai pasar (misalnya Gambling dan karim dalam Triyuwono 2009). Nilai pasar dalam net realizable value memberikan gambaran keadaan ekonomi yang sebenarnya dibandingkan dengan historicalcost (misalnya Bakar 2007 dalam Farhan). Net realizable value merupakan metode yang tepat untuk mengitung nilai aset nonkas untuk tujuan zakat.

Hal tersebut mengindikasikan bahwa penggunaan metode penilaian zakat dengan bistorical cost memberikan kesan spekulatif karena bistorical cost tidak memberikan gambaran sekarang nilai zakat. Sedangkan zakat yang dibayarkan harus mencerminkan nilai dari kekayaan sekarang yang dimiliki oleh bank. Adanya penggunaan historical cost pada penilaian zakat berarti nilai aset yang dijadikan objek zakat berpatokan pada nilai kas yang dikeluarkan untuk memperoleh aset tersebut. Padahal aset tersebut nilainya tidak selalu konsisten dari tahun ketahun. Hal tersebut memunculkan jumlah zakat yang dibayarkan oleh bank lebih rendah dari yang seharusnya. Contohnya tanah ataupun bangunan yang selalu mengalami renovasi atau perbaikan dari tahun ke-tahun yang memiliki nilai yang cenderung naik. Ketika aset tetap tersebut dinilai berdasarkan bistorical cost berarti jumlah zakat yang dikeluarkan lebih rendah dibandingkan dengan menggunakan net realizable value atau nilai realisasi bersih, karena nilai aset nonkas seperti tanah dan bangunan cenderung mengalami kenaikan.

Penggunaan historical cost dalam penilaian aset tetap yang akan dijadikan objek zakat memberikan kesan spekulatif dari bank karena jumlah zakat yang dibayarkan tidak sesuai dengan nilai yang dapat direalisasikan dari aset tersebut. Dan dalam Islam sikap spekulatif tidak boleh diterapkan karena menunjukkan ketidakadilan dalam penyajian informasi. Hal ini menegaskan bahwa penggunaan hisorical cost yang memberikan peluang bagi Bank Syariah untuk mengeluarkan zakat yang lebih kecil dari yang seharusnya karena adanya penilaian aset tetap yang terlalu rendah seperti tanah dan bangunan padahal nilai tanah yang cenderung naik dan bangunan jika mengalami perawatan dan tempatnya straegis cenderung nilainya juga akan 
AL-MASHRAFIYAH: Jurnal Ekonomi, Keuangan, dan Perbankan Syariah

Volume 3, Nomor 1, April 2019

naik. Ini mengindikasikan bahwa hal tersebut mengandung unsur maysir atau spekulatif tidak diperbolehkan dalam Islam bahkan perbuatan tersebut haram hukumnya.

\section{Unsur Kezaliman dalam Penanggungan Biaya Perbaikan Pembiayaan Ijarah}

Kezaliman didefinisikan sebagai hal yang merugikan diri sendiri maupun orang lain. Dalam tulisan ini kezaliman diartikan memperlakukan sesuatu tidak sesuai tempatnya/posisinya. Hal ini dilakukan dengan mengidentifikasi pihak yang menanggung biaya perbaikan pada pembiayaan ijarah (sewa). Biaya perbaikan pada produk pembiayaan ijarah harus ditanggung oleh pihak yang benar-benar memiliki kewajiban menanggungnya. Hal ini tentunya menunjukkan bahwa Bank Syariah harus memperlakukan biaya perbaikan pada pembiayaan ijarah sesuai dengan posisinya.

Pelaksanaan pembiayaan ijarah Bank Syariah tidak dilakukan dengan sendirinya, artinya sebelum bank melakukan akad ijarah terlebih dahulu nasabah dan bank melakukan akad musyarakah. Akad musyarakah yang dilakukan oleh bank dan nasabah menunjukkan kepemilikan bank dan nasabah 90:10 (bank 90 dan nasabah 10). Salah satu contoh akad ijarah yang didahului dengan akad musyarakah dilakukan oleh Bank yaitu pembangunan gedung. Gedung tersebut dibangun dengan modal bank 90\% dan modal nasabah 10\%. Hal itu menunjukkan adanya kemitraan dalam pembangunan gedung tersebut atau akad musyarakah. Selama pembangunan gedung tersebut biaya perbaikan ditanggung oleh bank dan nasabah berdasarkan kepemilikan modal. Sebagaimana pernyataan dari Ibu Nur Qalbi;

"Bank melakukan akad ijarah dengan didahului dengan akad musyarakah. Artinya ketika ada kerusakan selama pembangunan misalnya properti yang menjadi objek ijarah maka pihak yang menanggung biaya perbaikan adalah nasabah dan bank sesuai dengan proprorsi modal misalnya 90: 10".

Sedangkan setelah selesainya pembangunan tersebut yang ditandai dengan dimulainya akad ijarah maka yang menanggung biaya perbaikan adalah nasabah. Hal itu karena kepemilikan bank akan berubah menjadi $0 \%$ sementara kepemilikan nasabah menjadi 100\%, ini karena akad ijarah didasari dengan akad musyarakah. Sebagaimana pernyataan dari Bapak Muhidin;

"Untuk biaya perbaikan tetap ditanggung oleh nasabah karena kepemilikan dari bank akan semakin berkurang sampai 0 bagian dan nasabah menjadi 100\%".

Penjelasan tersebut mengidentifikasikan bahwa pihak yang menanggung biaya perbaikan pada pembiayaan ijarah adalah nasabah sebagai pihak yang memiliki gedung pada akhir pembayaran akad musyarakah. Hal ini mengindikasikan bahwa pihak yang menanggung biaya perbaikan haruslah pemilik dari gedung tersebut. Dalam hal ini pembiayaan ijarah merupakan akad yang diperjanjikan oleh bank dan nasabah untuk melakukan bagi hasil, artinya adanya akad ijarah karena adanya akad musyarakah.

Di luar dari pada itu jika melihat perlakuan biaya perbaikan tersebut maka bank sudah menghindari konsep substance over form. Dimana penyewa tidak lagi menanggung biaya perbaikan gedung, melainkan ditanggung oleh pemilik (bank dan nasabah). Substance over form yang artinya bank memperlakukan biaya perbaikan berdasarkan penggunaan manfaat ekonomis objek yang disewakan. Substance over form pada hakekatnya lebih mementingkan transaksi dari pada bentuk hukum transaksi itu sendiri. Konsep substance over form pada pengakuan beban bank akan menimbulkan kepercayaan bahwa pihak bank sebagai pemilik dari objek ijarah tidak perlu menanggung biaya perbaikan yang timbul dari objek ijarah karena bentuk hukum kepemilikan tersebut tidak penting lagi, karena pihak yang menikmati manfaat ekonomis objek ijarah tersebutlah yag harus menanggung biaya tersebut. Sehingga konsep ini mengakibatkan laba yang diperoleh akan lebih tinggi karena ada beban yang tidak perlu diakui oleh bak yaitu beban perbaikan yang berasal dari objek ijarah, atau dengan kata lain konsep 
Angriani, et al. Penerapan Sharia Compliance Sebagai Prinsip...

substance over form memberikan pemahaman bahwa ada beban yang boleh tidak diakui dan hal tersebut memunculkan kezaliman bagi nasabah atau dalam hal ini penyewa.

Ketentuan syariah tidak mengenal konsep ini karena seluruh transaksi didasarkan atas akad dan akad tersebut selalu sama antara bunyi akad (dalam bentuk hukum) dengan substansi dari akad itu sendiri. Yang berarti ketika terjadi akad ijarah, yang menanggung biaya perbaikan adalah pemilik dari objek yang disewakan tersebut. Beda halnya dengan konsep substance over form, biaya perbaikan ditanggung oleh penyewa karena penyewa yang menikmati manfaat ekonomis dari objek yang disewakan tersbut. Konsep substance over form menunjukkan adanya kezaliman, terkhusus dalam perlakuan biaya perbaikan. Adanya pemahaman bahwa pihak yang menanggung biaya adalah pihak yang menyewa karena merupakan pihak yang menikmati manfaat dari objek ijarah tersebut.

\section{PENUTUP}

Penghindaran unsur riba pada Bank Muamalat dilakukan dengan menghindari prinsip time value of money dimana konsep ini merupakan turunan dari konsep dasar akuntansi historical cost, hal ini karena time value of money mengandung bunga dalam pembayaran tangguhan. walaupun unsur riba belum bisa dihindari secara menyeluruh karena margin keuntungan dari pembiayaan murabahah masih didasarkan pada seberapa lama periode pembayaran dilakukan. Penghindaran unsur gharar dilakukan dengan menghindari konsep dasar akuntansi accrual basic, hal ini karena accrual basic mengandung ketidakjelasan dalam kaitannya dengan pengakuan pendapatan pada pembiayaan mudharabah, artinya pendapatan diakui ketika pendapatan telah terealisasi. Penghindaran unsur maysir dilakukan dengan menghindari konsep dasar akuntansi bistorical cost dalam penilaian aset tetap dalam kaitannya dengan pembayaran zakat, artinya aset tetap dinilai berdasarkan nilai sekarang (pasar) yang dapat direalisasikan. Penghindaran unsur kezaliman dilakukan dengan menghindari konsep dasar akuntansi substance over form dalam kaitannya dengan penanggungan biaya perbaikan atas objek ijarah, artinya pihak yang menanggung benar-benar pihak tepat atau sesuai dengan posisinya. Sedangkan penerapan prinsip tawazun, universalisme dan maslahah dilakukan melalui kegiatan sosial dari dana CSR dan zakat. Dengan adanya penerapan zakat maka tujuan dari Bank Muamalat bukan lagi profitoriented melainkan zakat-oriented. Dalam artikel ini mengungkap bahwa pengelolaan produkproduk Bank Muamalat Cabang Makassar belum sepenuhnya menerapkan syariah compliance yang merupakan prinsip utama syariah governance.

Perbedaan tingkat pemahaman mengenai aplikasi prinsip syariah pada menggambarkan adanya perbedaan kesadaran dalam menjalankan praktik Syariab Governance. Bank Muamalat Indonesia Tbk Cabang Makassar, telah berusaha menerapkan prinsip syariah meskipun belum sepenuhnya dapat menghindari konsep-konsep konvensional dalam pengelolaannya terutama pemilihan konsep dasar dalam memperlakukan transaksi-transaksi yang terjadi. Sehingga pada masa yang akan datang, diharapkan Bank Muamalat Indonesia Tbk. Cabang Makassar, benarbenar menerapkan nilai Islam melalui penerapan prinsip syariah baik dari segi konsep maupun prakteknya. Nilai-nilai Islam yang tercermin dalam prinsip-prinsip syariah memanglah harus menjadi dasar penyusunan standar akuntansi syariah. Dengan adanya penelitian ini maka memberi manfaat bagi pembuatan standar akuntansi syariah. Khususnya dalam penentuan konsep dasar yang sesuai untuk menyusun laporan keuangan lembaga keuangan syariah utamnya dalam hal ini Bank Muamalat Indonesia Tbk Cabang Makassar.

\section{DAFTAR PUSTAKA.}

Abdullah Saif Alnasser, S., \& Muhammed, J. (2012). Introduction to corporate governance from Islamic perspective. Humanomics, 28(3), 220-231.

Asrori, P. S. C. Kepatuhan Bank syariah terhadap Prinsip Shari'ah. Jurnal Dinamika Akuntasi, 3. 
AL-MASHRAFIYAH: Jurnal Ekonomi, Keuangan, dan Perbankan Syariah Volume 3, Nomor 1, April 2019

Amiruddin, K. (2017). Konseptualisasi Ekonomi Dan Keuangan Syariah. Al-Mashrafiyab: Jurnal Ekonomi, Keuangan, dan Perbankan Syariah, 1(1).

Bashori, A. (2013). Pendekatan Hermeneutika: Sebuah Paradigma Dan Kerangka Metodologi. Semarang. Institut Agama Islam Negeri W alisongo.

Cahya, B. T. (2013). Kilas Kebijakan Good Corporate Governance Pada Perbankan Syariah di Indonesia. La_Riba: Jurnal Ekonomi Islam, 7(1), 15-28.

Darwis, D. (2018). Minat Masyarakat Kota Watampone Untuk Menggunakan Jasa Perbankan Syariah. Al-Mashrafiyah: Jurnal Ekonomi, Keuangan, dan Perbankan Syariah, 2(1).

Dusuki, A. W., \& Abdullah, N. I. (2007). Maqasid al-Shariah, Maslahah, and corporate social responsibility. American Journal of Islamic Social Sciences, 24(1), 25.

Ghayad, R. (2008). Corporate governance and the global performance of Islamic banks. Humanomics, 24(3), 207-216.

Hamza, H. (2013). Sharia governance in Islamic banks: effectiveness and supervision model. International Journal of Islamic and Middle Eastern Finance and Management, 6(3), 226237.

Mu'allim, A. (2003). Persepsi Masyarakat terhadap Lembaga Keuangan Syariah. Al-Mawarid Journal of Islamic Law, (10).

Wijaya, A. (2015). Dimensi Ilahi Dan Dimensi Insani Dalam Maqasid Al-Syari'ah. Al-Risalah Jurnal Ilmu Syariah dan Hukum, 15(2), 214-221.

Muchlis, Saiful, (2011). Akuntansi Perbankan Syari'ah, Alauddin Press: Makassar.

Mulyana, E. (2012). Belajar Hermeneutika dari Konfigurasi Filosofis Menuju Praksis Islam Studies.

Naser, K., \& Pendlebury, M. (1997). The influence of Islam on bank financial reporting. International Journal of Commerce and Management, 7(2), 56-83.

Iriani Pujiastuti, Y. (2012). Analisis Atas Ketaatan Penyajian Laporan Kenangan Perusabaan Terbuka Di Indonesia.

Riharjo, I. B. (2011). Memahami Paradigma Penelitian Non-Positivis medan Implikasinya dalam Penelitian Akuntansi.Jurnal Akuntansi, Manajemen, Bisnis dan Sektor Publik (Jambsp), 8(1), 128-146.

Santoso, E. W. A. (2007). Faktor Relegiusitas Dalam Perbankan Syariah. VALUE ADDED| MAJALAH EKONOMI DAN BISNIS, 4(1).

Saputro, Andik S. Dwi. (2010). Penguatan Sharia Governance Melalui Reformasi Akuntansi, Simposium Nasional Akuntansi XIII Purwokerto, h. 1-32.

Shaharuddin, Amir. Maslahah-Mafsadah Approach in Assessing the Shariah Compliance of Islamic Banking Products. International Journal of Business and Social Science. Vol. 1 No. 1 , (2010): h. 129-136.

Sukardi, Budi, Kepatuhan Syariah (Shariah Compliance) Dan Inovasi Produk Bank Syariah Di Indonesia, Stainmetro.Ac.Id/E-Journal/Index.php.

Thohari, A. (2013). Epistemologi Fikih Lingkungan: Revitalisasi Konsep Masalahah. Az Zarqa': Jurnal Hukum Bisnis Islam, 5(2). 
Angriani, et al. Penerapan Sharia Compliance Sebagai Prinsip...

Triyuwono, I. (2006). Perspektif, Metodologi, dan Teori Akuntansi Syariah. PT RajaGrafindo Persada.

Ulfah, M. (2012). Analisa Perkembangan Asset, Dana Pibak Ketiga (DPK), dan Pembiayaan Perbankan Syariah di Indonesia.

Wardayati, S. M. (2011). Implikasi Shariah Governance Terhadap Reputasi dan Kepercayaan Bank Syariah. Walisongo: Jurnal Penelitian Sosial Keagamaan, 19(1), 1-24.

Wibowo, E. (2007). Dimensi Keadilan dalam Epistimologi Akuntansi Syariah. VALUE ADDED | MAJALAH EKONOMI DAN BISNIS, 3(2).

https://www.bankmuamalat.co.id/profil-bank-muamalat 